ACTA AGROBOTANICA

Vol. 62 (2): 213-230

2009

\title{
THE OCCURRENCE OF Papaver rhoeas L. IN AGROCENOSES OF THE BUFFER ZONE OF THE ROZTOCZE NATIONAL PARK COMPARED TO OTHER REGIONS OF POLAND
}

\author{
Czesława Trąba, Marta Ziemińska-Smyk ${ }^{1}$ \\ Department of Agroecology, University of Rzeszów, M. Ćwiklińskiej 2/D3; 35-601 Rzeszów, Poland \\ e-mail: ctraba@univ.rzeszow.pl \\ ${ }^{1}$ Department of Biology of Plant Faculty of Agricultural Sciences in Zamość University of Life Sciences in Lublin, \\ Szczebrzeska 102; 22-400 Zamość, Poland
}

Received: 2.02.2009

$$
\text { Abstract }
$$

The paper tries to determine the environmental amplitude as well as the optimal conditions for the vegetation of Papaver rhoeas in the agrocoenoses of the Roztocze National Park's buffer zone, as compared to other Polish regions. The analysis is based on certain habitat and anthropogenic factors. Based on the author's own research and the data quoted in the literature, it has been found that Papaver rhoeas occurs in the associations and communities of the Caucalidion and Aperion alliances accompanying cereal and rape crops as well as in the PolygonoChenopodion and Panico-Setarion alliances accompanying root crops. Papaver rhoeas demonstrates a large environmental scale, as its presence has been noted in low- and highlands, in foothills, in river valleys as well as on slopes. Moreover, it teams up with various types of soils (of a wide range of acidity, moisture as well as trophic and thermal conditions) and complexes. Papaver rhoeas occurs most often and in the largest numbers in winter crops in the Lathyro-Melandrietum and Caucalidio-Scandicetum association which belongs to the Caucalidion alliance and in the Consolido-Brometum, Vicietum tetraspermae papaveretosum and V.t. consolidetosum association from the Aperion alliance. As far as root crops are considered, Papaver rhoeas shows up in the Lamio-Veronicetum politae association from the PolygonoChenopodion alliance. It prefers chalky and Jurassic rendzinas containing $\mathrm{CaCO}_{3}$ and other fertile loam and loess soils which belong to wheat complexes, with their $\mathrm{pH}$ ranging from slightly acid to alkaline (Eutric Vertisols, chernozem, brown soil, alluvial soil) and which are moderately moist, warm, medium-rich in nitrogen and with good soil biological activity. In the foothill areas, it dominates on alluvial soils in the river valleys; rarely has it been spotted on the slopes. Papaver rhoeas rarely occurs on the lightest sandy soils of the weak and very weak rye complexes and weak cereal-fodder complexes. The distribution of Papaver rhoeas reflects the soil conditions in a given area.

Key words: Papaver rhoeas, phytoindication, chemical properties of soil, relevé, plant associations, ecological scale

\section{INTRODUCTION}

Papaver rhoeas, red poppy, occurs in the warm and temperate parts of Europe, becoming less and less frequent when moving to the North of the continent (M a r k o w , 1978). In Poland it grows in the lowland and foothills, usually up to $600 \mathrm{~m}$ a.s.l. (Hoch ó 1 , 2001; Łabza, 1994; W ó j cik, 1977; 1998). The poppy is an archeophyte originating from the Mediterranean and Irano-Turanian zone. As early as at the beginning of the Neolithic Age, it was a weed of cereal crops on the territory of today's Poland (L i t y ń s k a $\mathrm{Zaj}$ ą c, 2005).

Papaver rhoeas is an annual, mainly winter plant, occurring in winter and spring cereal crops, rape and root crops, in addition on fallows, near farm buildings, along fences and train rails (Fijałkowski, 1978). In cereal crops it blossoms from May to August and in root crops from August to October (M a r k o w, 1978). It belongs to the layer created by cereals or slightly overgrows them. While dominating in agrocenoses, Papaver rhoeas contributes to their colourful aspect during the bloom period (S i c ińs ki, 1993). In Lubelszczyzna, E Poland, in winter crops the red poppy enters the phase of maturing and seed dispersal from the end of June to August, in spring cereals from the end of July to the end of August, and in root plant crops in September up to the second decade of October (J ę d r u s z c z a k, 1993). It belongs to the most prolific and short-lived weeds ( $\mathrm{Paw}$ tow s ki et al. 1970) and it is included in the eighth ecological group of short-lived archeophytes commonly found on calcareous and other nutrient-rich and moderately moist soils (Hilbig et al. 1962). It is a characteristic species for the Centauretalia cyani order and the Stellarietea mediae class (M a t u s z k i e w i c z, 2005). 
Reviewing rich Polish literature on segetal flora, W a r c hol i ń s k (1994) mentioned Papaver rhoeas among 100 other species on the list of threatened and disappearing weed species in Poland. She assigned to it the status of a species of unidentified threat, which was backed up by numerous other studies, including the one estimating that the population of Papaver rhoeas shrank in the 1990s by $30-50 \%$ compared to the period 1947-1967 (F i jałk ow s ki and N y c z , 1998). Similarly S k r z y c z y ń s k a (1994) observed a lower constancy class and species cover index of Papaver rhoeas in various associations on the Siedlce Plateau (north from the Lublin Region). Also P a w la k (1998) draws attention to the extinction threat of this species. On the other hand, however, Papaver rhoeas is not considered a disappearing weed species on the Miechów Upland (D a b k ow s k a et al. 2007) and Silesian Upland (U r b is z et al. 1998), and in Opole Silesia (A n i o ł-K w i a t k o w s k a and Now a k, 2006).

The goal of the present study was an attempt to define the ecological amplitude and optimal conditions for Papaver rhoeas in the buffer agrocenoses of the Roztocze National Park as compared to other Polish regions, depending on the selected site and anthropogenic factors. This analysis was also inspired by the lack of wide ecological studies on the ecology of rare and disappearing weeds of agricultural crops, including Papaver rhoeas.

\section{STUDY AREA}

The Roztocze National Park (RNP) was established in 1974. The area of its buffer zone amounts to 38,096 hectares. Its diversified geological substratum, hydrological conditions and relief determine the spatial variability of soils in the park and its buffer zone. On the slopes and ridges, the dominating soil types are brown soils on loess, leached brown soils on gaizes, composed of loams and sands, as well as chalky rendzinas. While vast areas are covered by grey-brown podzolic soils developed from sands with different grain-size distribution, loamy greybrown podzolic soils occupy only a small portion of the study area. The climate conditions are chiefly determined by insolation and atmospheric circulation modified by the altitude, exposure of slopes, type of substratum and its cover (T u r s k et al. 1993).

From the physiographic point of view, the northern part of the RNP belongs to the Zamość Valley, the central part to Roztocze, while the north-western part to the Biłgoraj Plain.

\section{MATERIALS AND METHODS}

Among 574 phytosociological relevés taken in 1991-1995 on plots of approximately $100 \mathrm{~m}^{2}$ each in agrocenoses of the RNP buffer zone, 306 represented cereal crops, 240 root crops, and the rest - fallow and idle lands. In cereals the releves were taken in two replicates: at the end of May and in the first half of July, and in root crops at the end of August/beginning of September, whilst on fallow and idle land in the first half of July. From the total of 574 relevés, 196 were selected where Papaver rhoeas was present. Based on the species composition of those relevés, the following ecological indicators were calculated on a five-point scale of E 11 e n b e r g (1950): T (thermal conditions), W (soil humidity), R (soil acidity), $\mathrm{N}$ (nitrogen availability), and $\mathrm{G}$ (soil biological activity). Only the presence of species in relevés (not their cover-abundance) was considered. The results of phytoindication evaluation were subject to statistical analysis carried out with Statistica software. The frequency distributions of the ecological indicators T, W, R, N and G with medians are shown in the charts. The soil type was defined in the field with the use of agricultural soil maps at a scale of 1:5000. The granulometrics, $\mathrm{pH}$, content of humus, calcium carbonate and basic nutrients were determined in the laboratory in forty-six collective soil samples collected from the arable layer of crop fields, fallow and idle lands, wherever red poppy occurred. The evaluation of soil macronutrient availability was done according to the threshold numbers proposed by the Institute of Soil Science and Plant Cultivation (IUNG) in Puławy (Fertilising recommendations, 1985). The study area and the distribution of the locations with Papaver rhoeas are displayed on the map (Fig. 1). In Tables 2 and 3, only communities with the poppy present are presented.

\section{RESULTS}

Extensive farming as well as soil and microclimate diversity provide favourable conditions in the RNP buffer zone for the development of floristically diverse agrophytocenoses with Papaver rhoeas. Among 196 relevés, this species was considerably more frequent (approximately $70 \%$ of relevés) in cereal crops, on fallow and idle ground, than in root crops (Tab. 1). The biggest number of relevés (more than 43\%) represented Vicietum tetraspermae, an association that dominated in cultivated fields of the RNP buffer zone on various soil types and of different granulometric composition, ranging from the lightest sands to dusts and loams. In the root crops, most of the relevés (more than $16 \%$ ) represented the Lamio-Veronicetum politae association (Tab. 1) and only 2\% Echinochloo-Setarietum which, similarly like Vicietum tetraspermae, was the most widespread in the study area.

Almost $60 \%$ of the samples was represented by patches in which Papaver rhoeas occurred with the 
Table 1

Per cent of relevés with Papaver rhoeas L. in agrocenoses of the RPN buffer zone.

\begin{tabular}{lll}
\hline \multicolumn{1}{c}{ Association, community } & Subassociation & \% relevés \\
\hline Vicietum tetraspermae & typicum & 15.31 \\
\hline & papaveretosum & 14.80 \\
\hline Total: & consolidetosum & 13.27 \\
\hline Lathyro-Melandrietum & & 43.38 \\
\hline Caucalido-Scandicetum & 14.79 \\
\hline Avena fatua & 6.12 \\
\hline Elymus repens & 2.55 \\
\hline Echinochloo-Setarietum & 1.02 \\
\hline Galinsogo-Setarietum & 2.05 \\
\hline Lamio-Veronicetum politae & typicum & 1.53 \\
\cline { 2 - 3 } & fumarietosum & 14.28 \\
\hline Stellaria media & 2.04 \\
\hline Convolvulus arvensis & 4.08 \\
\hline Veronica persica & 2.04 \\
\hline Amaranthus retroflexus & 2.55 \\
\hline
\end{tabular}

degree of cover-abundance of " + ", and only $8.7 \%$ with the cover-abundance value of 3-4 in the Braun-Blanquet scale (Fig. 2). The cover-abundance of 1-4 was reached by Papaver rhoeas exclusively in the association Vicietum tetraspermae papaveretosum, often in Caucalidio-Scandiecetum, Lathyro-Melandrietum and in Vicietum tetraspermae consolidetosum and least frequently (only $6 \%$ of relevés) in Vicietum tetraspermae typicum. Among the segetal communities accompanying root crops, Papaver rhoeas at the cover-abundance level of 1-4 was most commonly found in Lamio-Veronicetum politae typicum, however, when Fumaria officinalis occurred in the association, the cover-abundance of Papaver rhoeas was only "+" (Fig. 3). The highest constancy classes and cover-abundance values of Papaver rhoeas in the mentioned associations are a consequence of the above phenomena (Tabs 2 and 3 ). In the RNP buffer zone, Papaver rhoeas was not found in several associations and communities accompanying cereal and root crops. They were phytocenoses oc- curring mainly on lighter, acid soils, or species-poor phytocenoses on fertile sites in intensive wheat cropping, treated with herbicides.

Considering the type and granulometric composition of soils in the RNP buffer zone, it was found that Papaver rhoeas was the most frequent on rendzinas (more than 50\% of relevés) and brown soils formed from gaize loams and loamy sands (more than 25\%), located on elevations exposed to south and south-west. It was less frequent on other types and kinds of soils, sporadically on grey-brown podzolic soils developed from slightly loamy sands (Fig. 4).

Papaver rhoeas occurred in almost all lowland complexes of soil agricultural use (Fig. 5), but most frequently (more than 50\% of relevés) in the defective wheat complex, usually composed of rendzinas. The largest areas of such soils occur in the Zamość Valley. The studied species exhibited the lowest frequency on soils of the weak rye and strong cereal-fodder complexes (Fig. 5). 


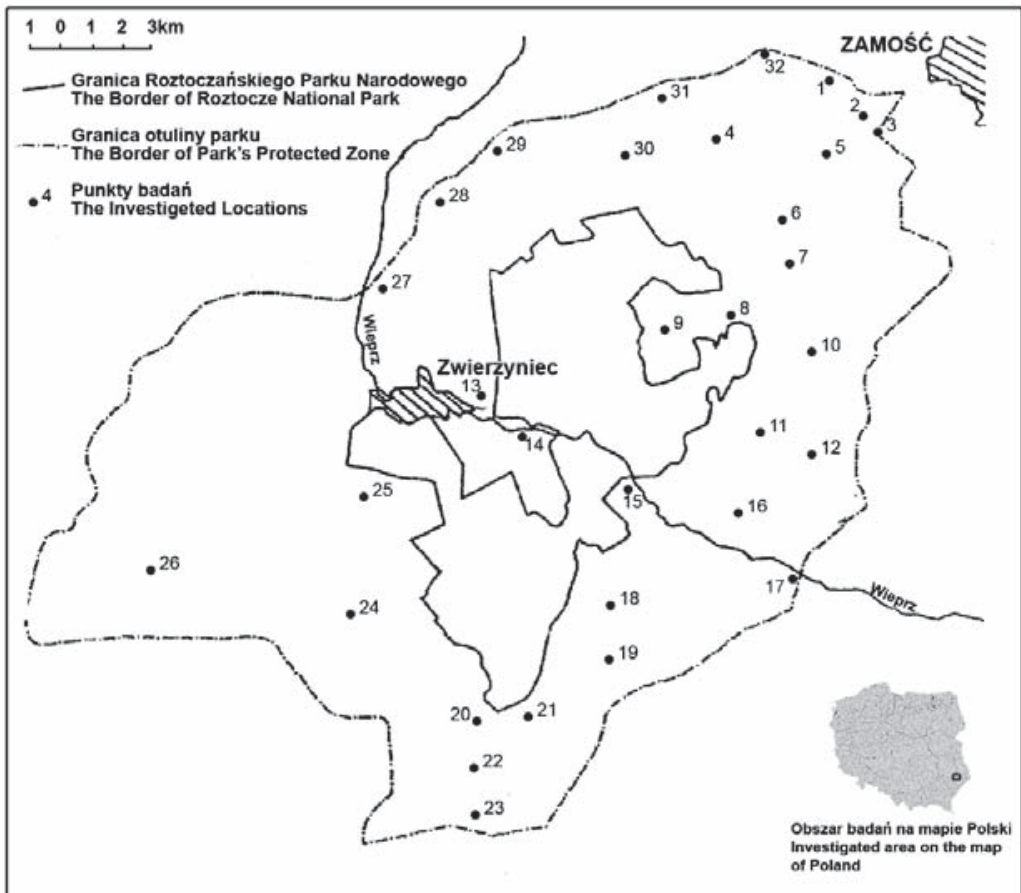

Fig. 1. Papaver rhoeas L. distribution in the buffer zone of the Roztocze National Park.

1 -Płoskie, 2-Mokre, 3 -Żdanówek, 4-Kąty II, 5-Hubale, 6-Wychody, 7 -Zarzecze, 8 -Wólka Wieprzecka, 9-Kosobudy, 10 - Szewnia Dolna, 11 - Bliżów, 12 - Adamów, 13 - Rudka, 14 - Obrocz, 15 - Guciów, 16 - Trzepieciny, 17 - Kaczórki, 18 - Stara Huta, 19 - Potok Senderki, 20 - Górecko Stare, 21 - Majdan Kasztelański, 22 - Brzeziny, 23 - Tarnowola, 24 - Tereszpol Kukiełki, 25 - Sochy, 26 - Bukownica, 27 - Żurawnica, 28 - Brody Małe, 29 - Brody Duże, 30 - Kolonia Niedzieliska, 31 - Niedzieliska, 32 - Siedliska.

Table 2

Constancy and cover index of field poppy Papaver rhoeas L. in segetal communities of cereal agrocenoses and fallows.

\begin{tabular}{llcc}
\hline \multirow{2}{*}{ Association, community } & Subassociation & $\begin{array}{c}\text { Number of } \\
\text { relevés }\end{array}$ & S* D** \\
\hline Vicietum tetraspermae & typicum & 51 & III 152 \\
\cline { 2 - 4 } & papaveretosum & 30 & V 1637 \\
\cline { 2 - 4 } & consolidetosum & 26 & V 487 \\
\hline Lathyro-Melandrietum & & 26 & V 821 \\
\hline Caucalido-Scandicetum & 12 & V 1508 \\
\hline Avena fatua & & 10 & III 296 \\
\hline Elymus repens & 5 & III 770 \\
\hline
\end{tabular}

$\mathrm{S}^{*}$ - constancy; $\mathrm{D}^{* *}-$ cover index 


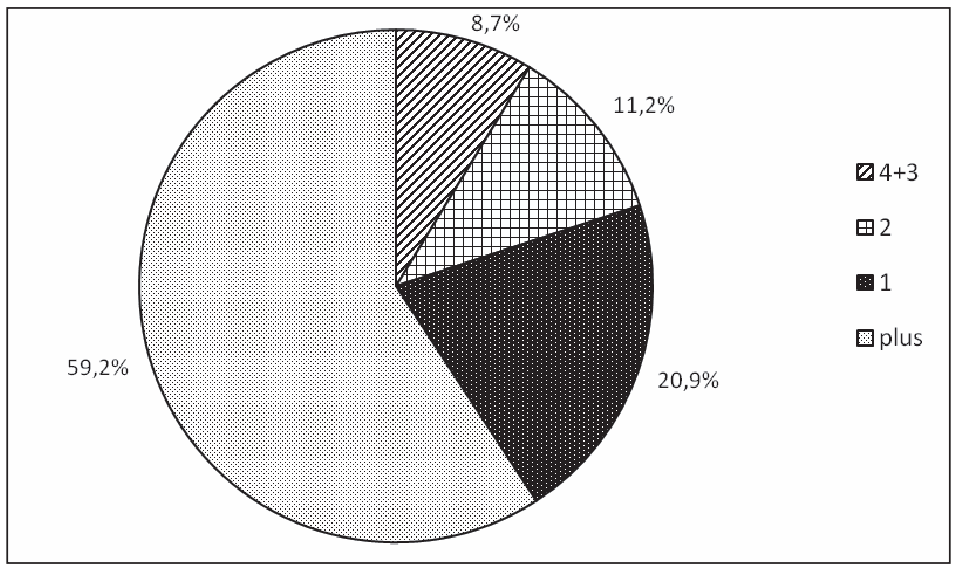

Fig. 2. Relative frequency of cover-abundance in relevés with Papaver rhoeas.

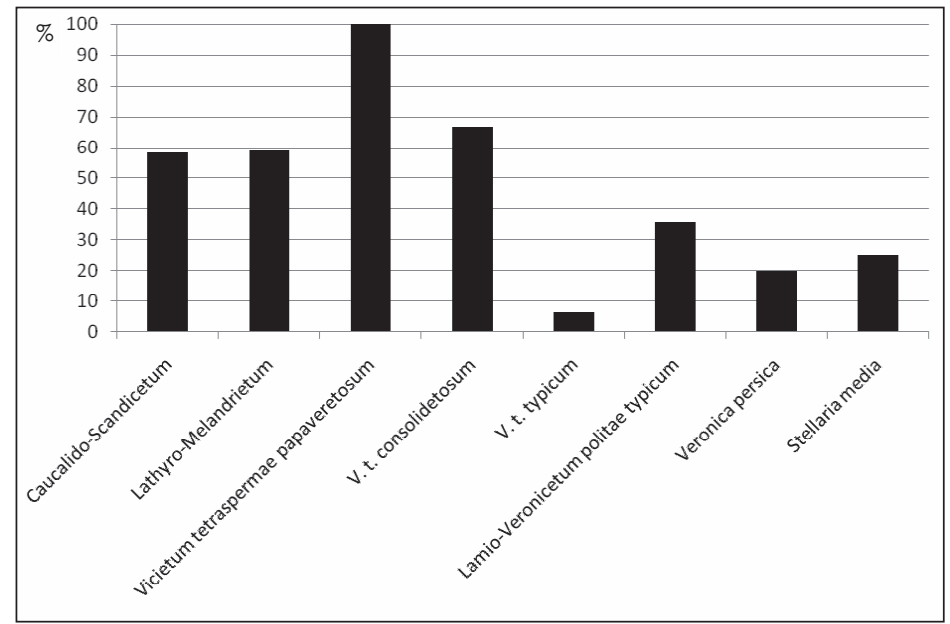

Fig. 3. Papaver rhoeas L. percentage proportion in cover-abundance (1-4) with reference to community type.

Table 3

Constancy and cover index of field poppy Papaver rhoeas L. in segetal communities of root plant agrocenoses.

\begin{tabular}{llcc}
\hline \multicolumn{1}{c}{ Association, community } & Subassociation & $\begin{array}{c}\text { Number of } \\
\text { relevés }\end{array}$ & S* $\mathrm{D}^{* *}$ \\
\hline Echinochloo-Setarietum & 18 & I 11 \\
\hline Galinsogo-Setarietum & 22 & II 10 \\
\hline Lamio-Veronicetum politae & typicum & 42 & V 720 \\
\cline { 2 - 4 } fumarietosum & 10 & II 20 \\
\hline Stellaria media & 17 & III 47 \\
\hline Convolvulus arvensis & 12 & III 27 \\
\hline Veronica persica & 8 & IV 40 \\
\hline Amaranthus retroflexus & 12 & IV 67 \\
\hline
\end{tabular}

$\mathrm{S}^{*}$ - constancy; $\mathrm{D}^{* *}$ - cover index 


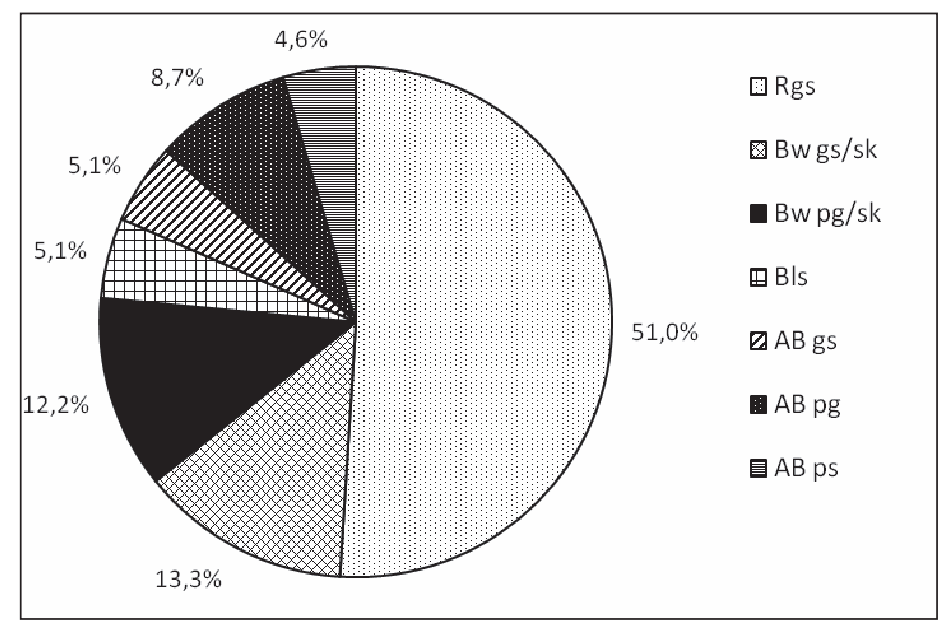

Fig. 4. Per cent of relevés with Papaver rhoeas in reference to soil type and granulometric composition of the arable layer. Explanations: R - rendzic; Bw - leached brown soils; B - brown soils; AB - grey-brown podzolic; gs - medium clay; pg - loamy sand; ls - less; ps - slightly loamy; sk - rock.

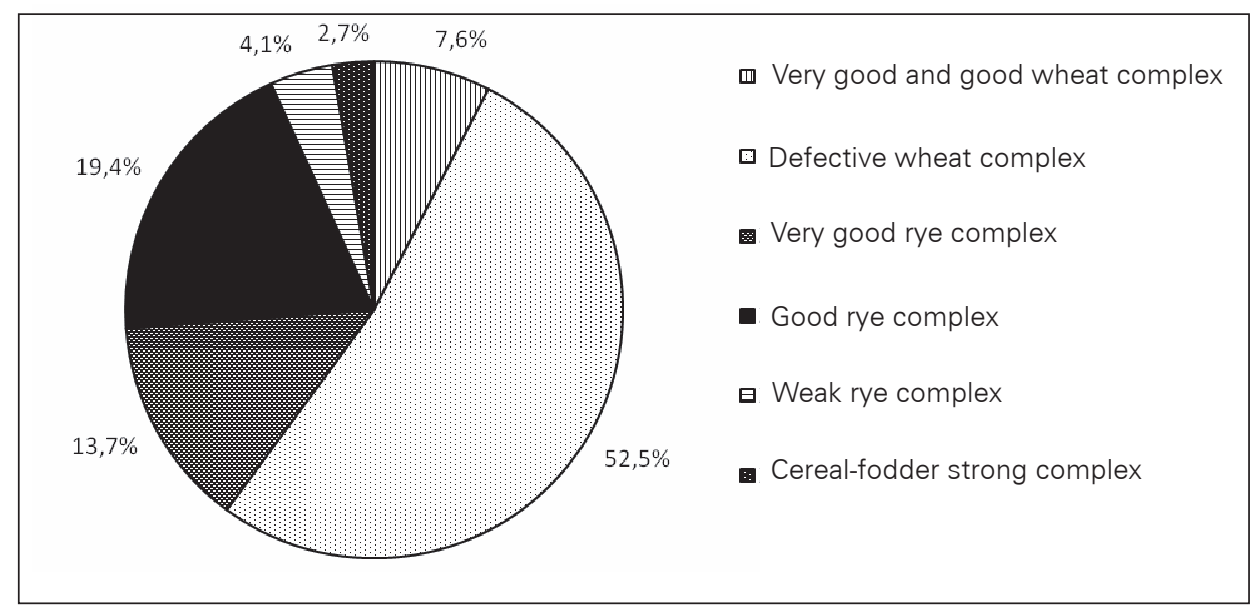

Fig. 5. Per cent of relevés with Papaver rhoeas in reference to the soil-agricultural complex. 


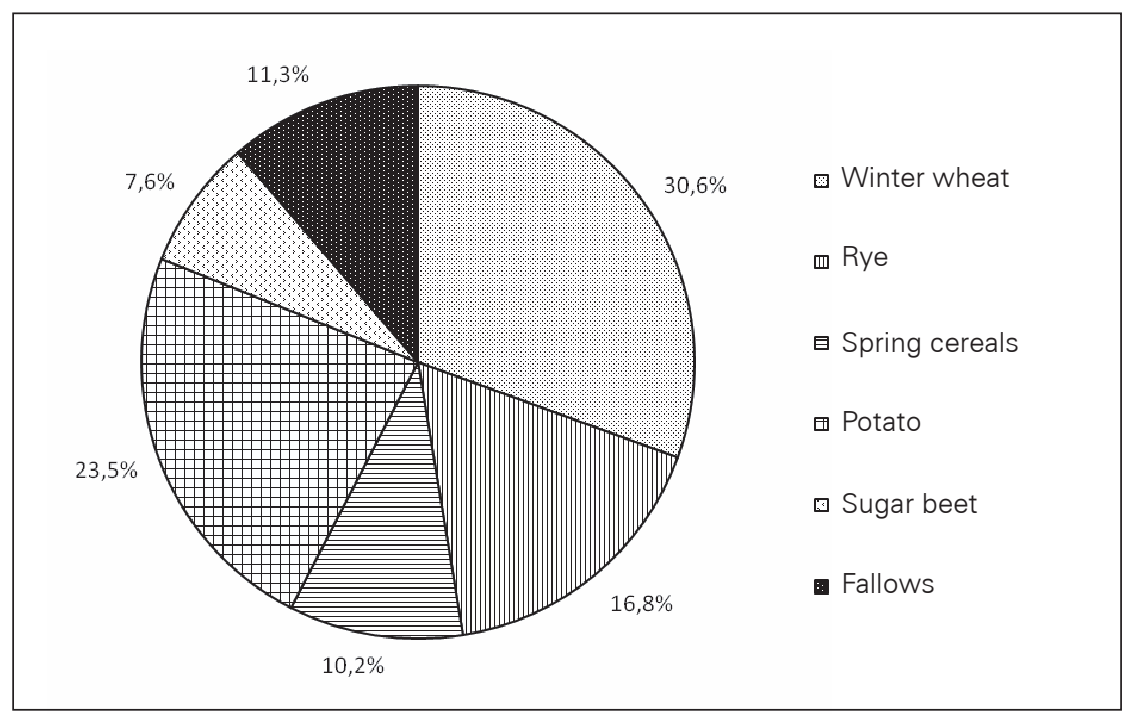

Fig. 6. Per cent of relevés with Papaver rhoeas in reference to crop.

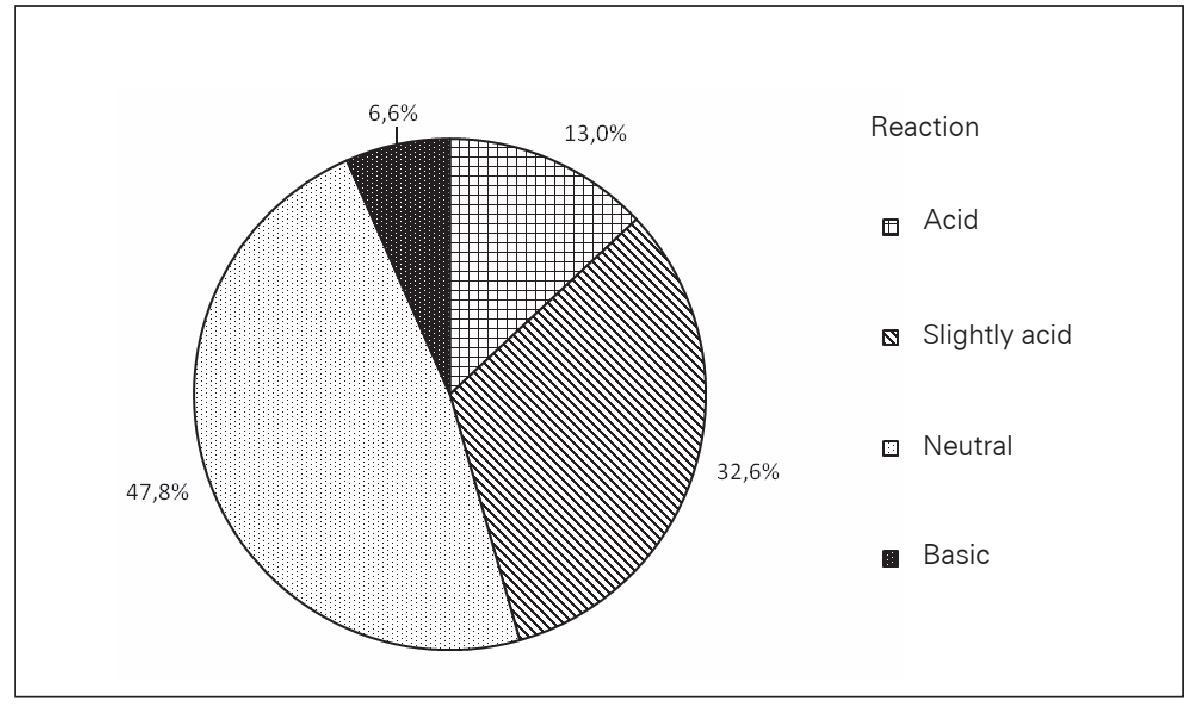

Fig. 7. $\mathrm{pH}$ of soil samples representing agrocenoses with Papaver rhoeas L. (\%samples). 


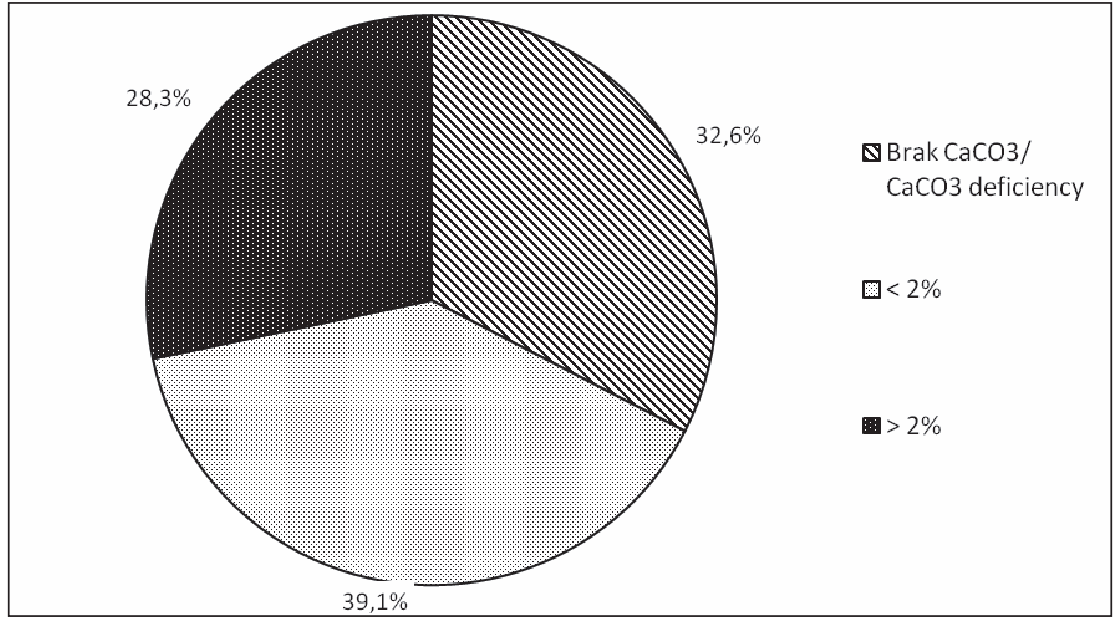

Fig. 8. $\mathrm{CaCO}_{3}$ content in soil samples representing agrocenoses with Papaver rhoeas L. (\% samples).

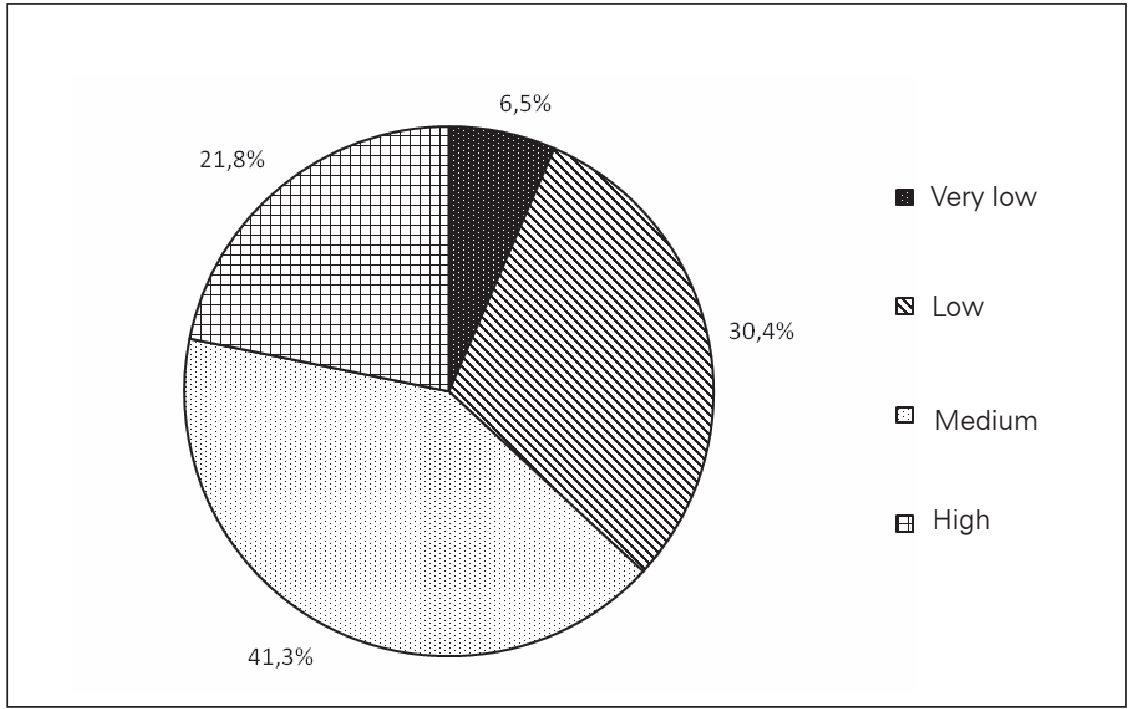

Fig. 9. Phosphorus content in soil samples representing agrocenoses with Papaver rhoeas L. (\% samples). 


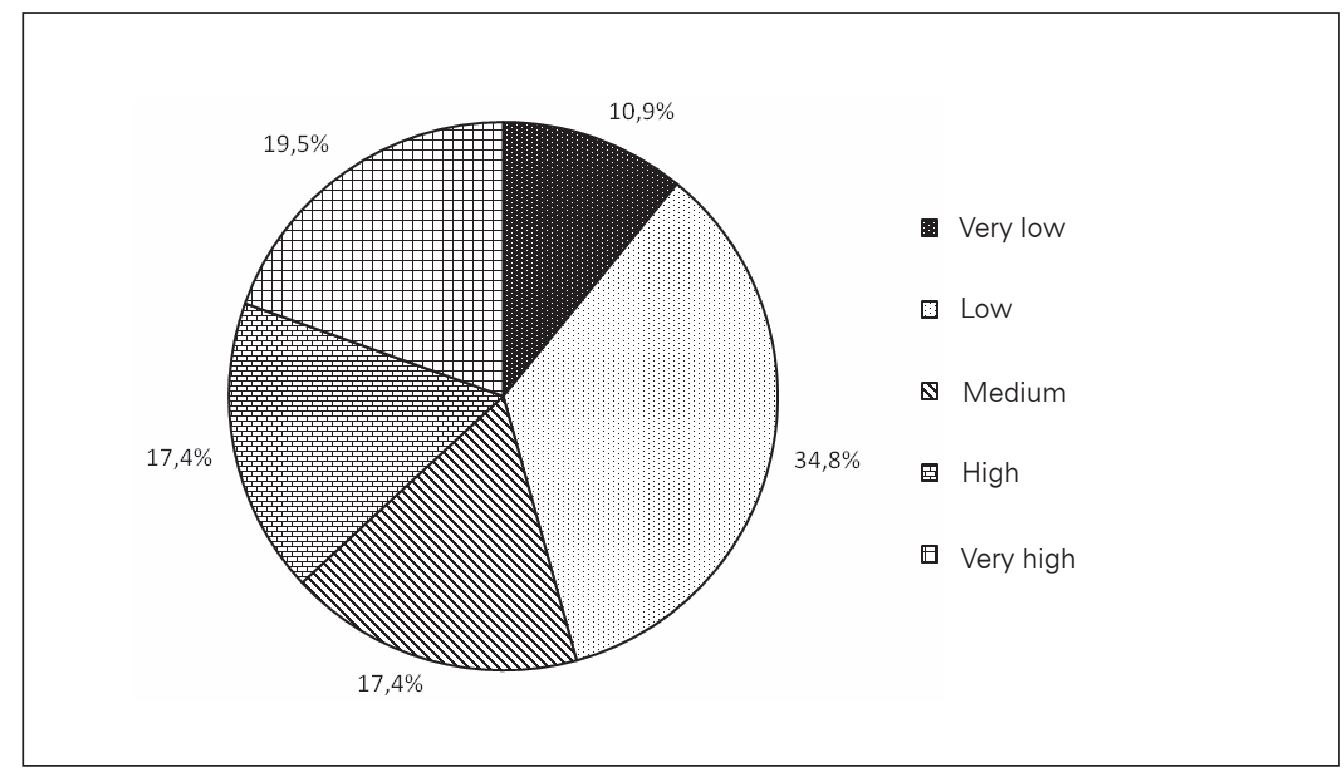

Fig. 10. Potassium content in soil samples representing agrocenoses with Papaver rhoeas L. (\% samples).

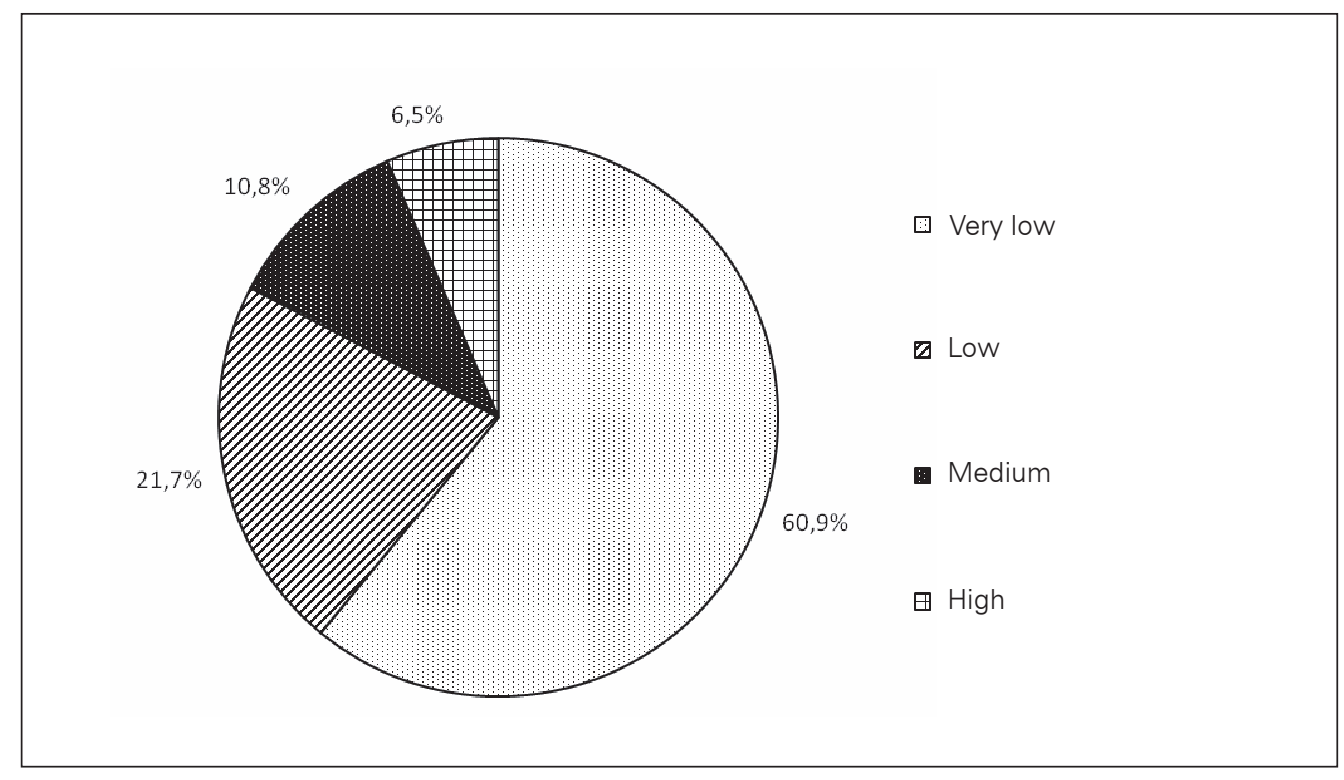

Fig. 11. Magnesium content in soil samples representing agrocenoses with Papaver rhoeas L. (\% samples). 


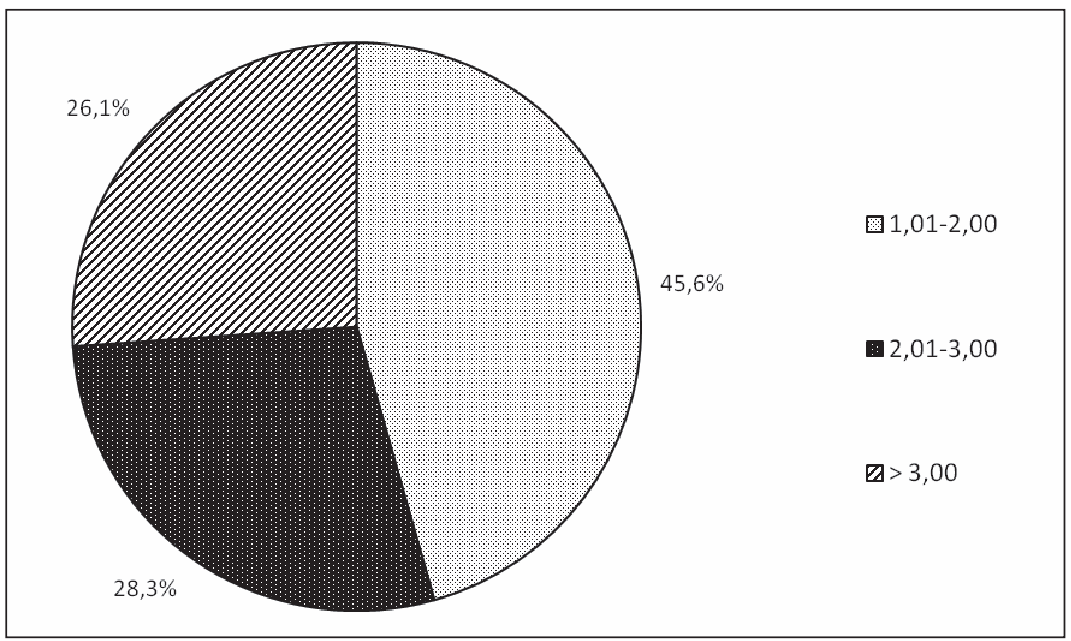

Fig. 12. Humus content in soil samples representing agrocenoses with Papaver rhoeas L. (\% samples).

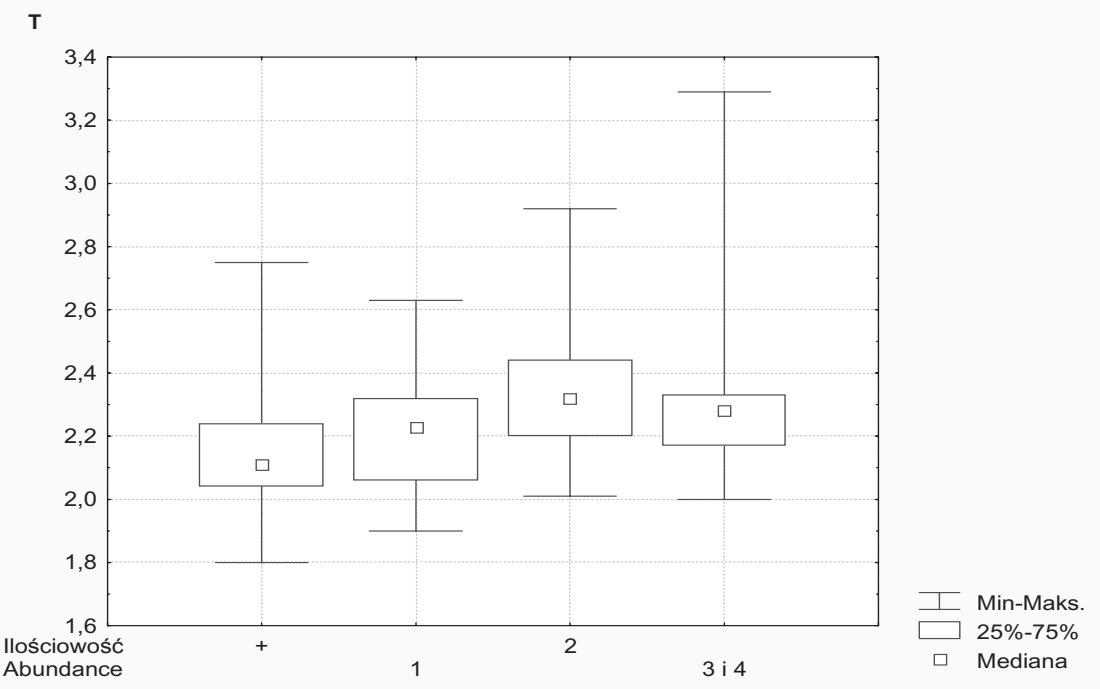

Fig. 13. The temperature $\mathrm{T}$ index range and medians. 


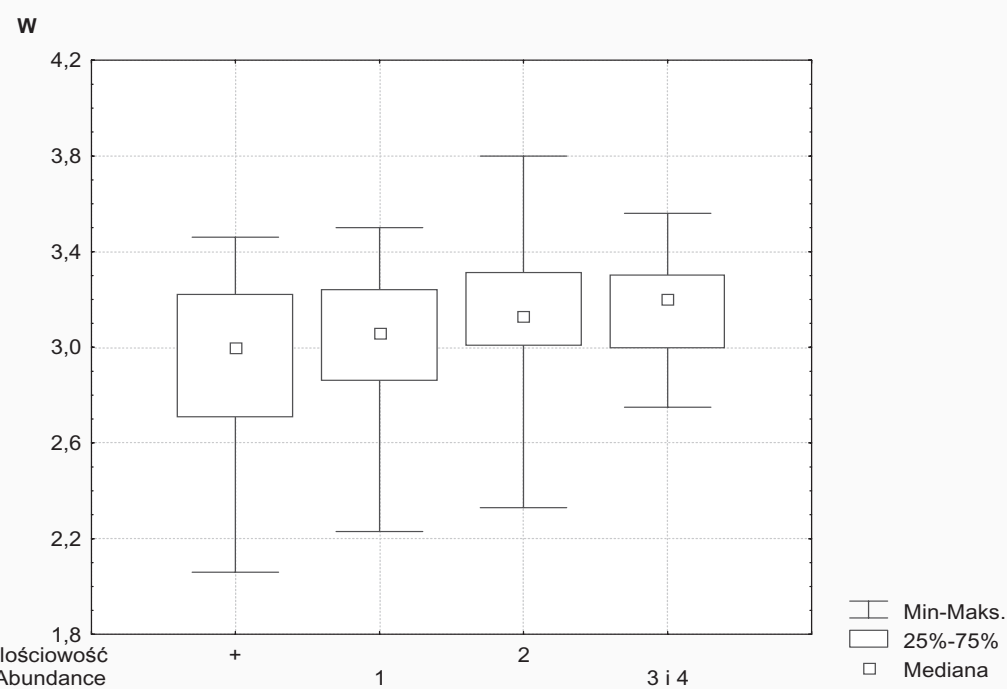

Fig. 14. The soil moisture $\mathrm{W}$ index range and medians.

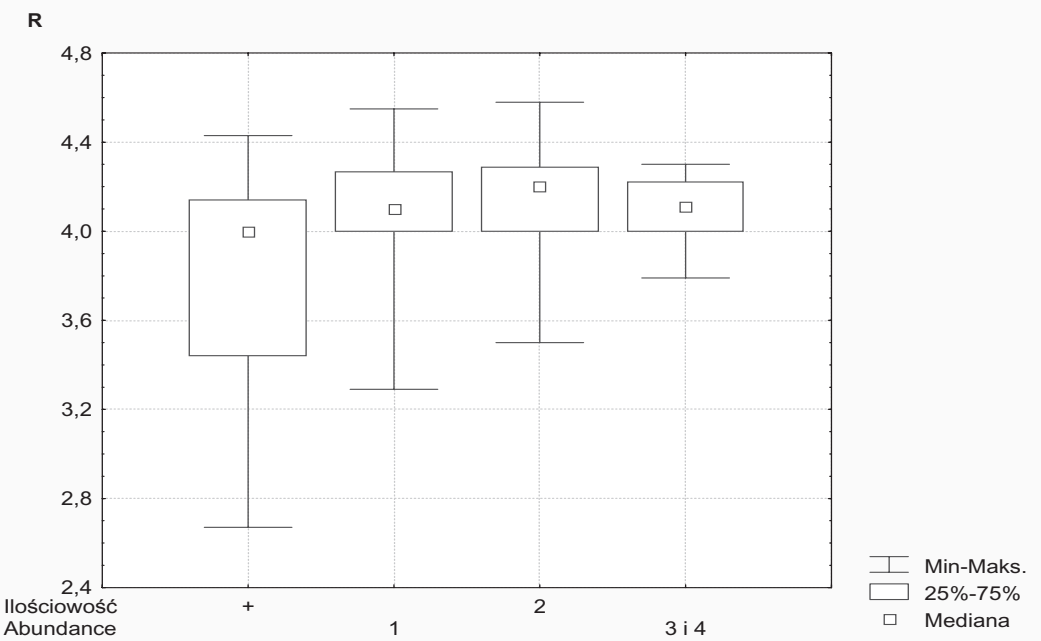

Fig. 15. The soil acidity $\mathrm{R}$ index range and medians. 


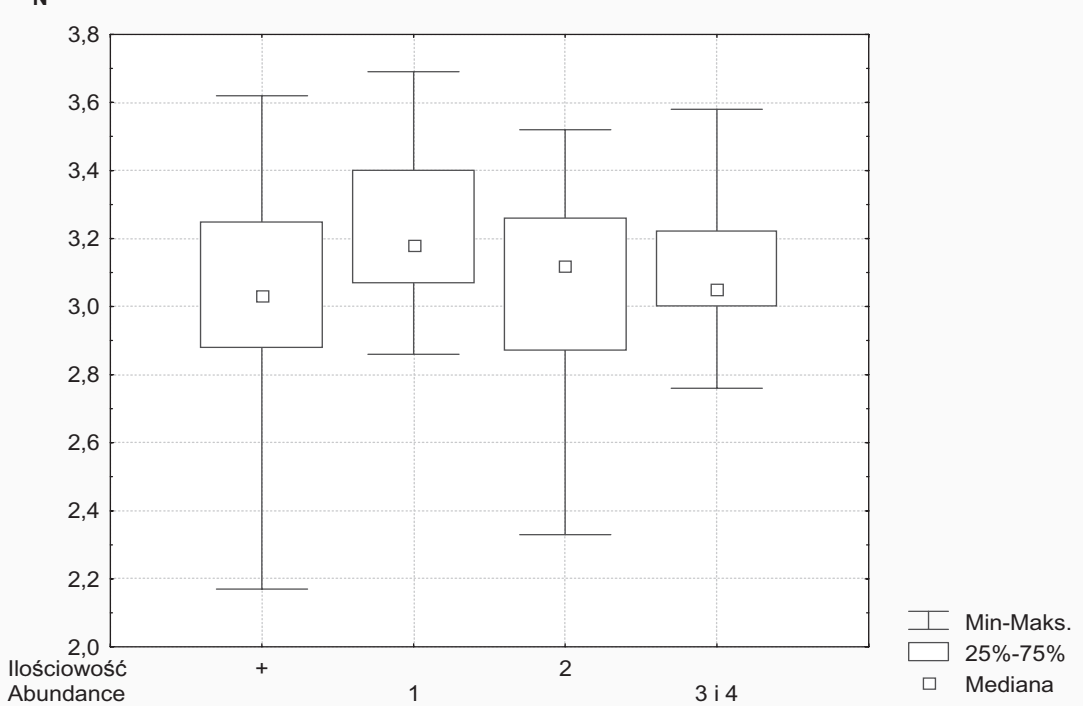

Fig. 16. The nitrogen content $\mathrm{N}$ index range and medians.

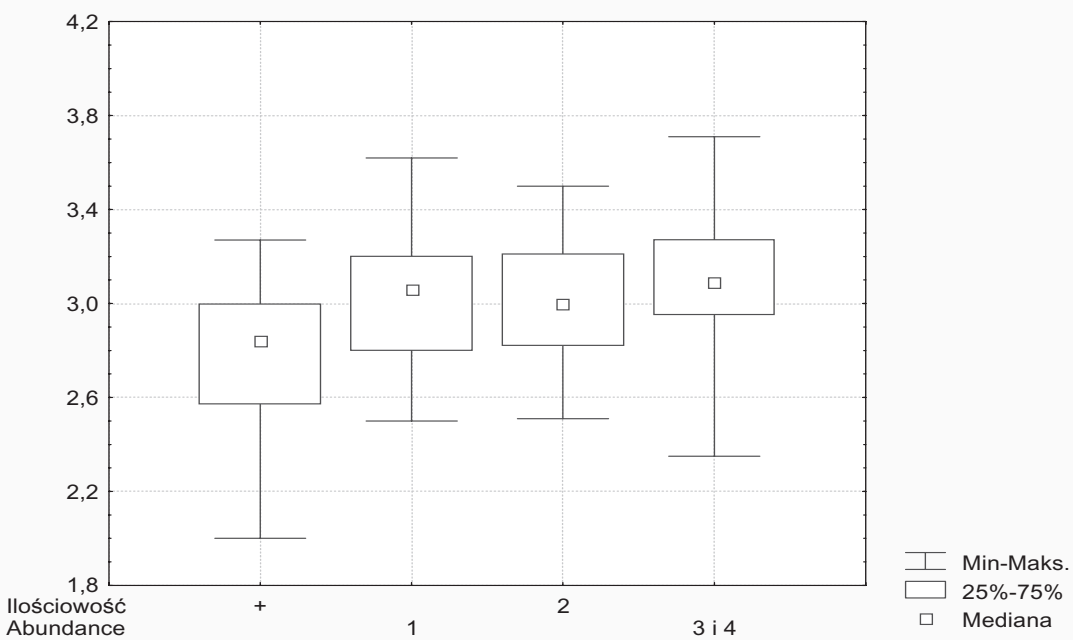

Fig. 17. The range and medians of the soil biological activity $\mathrm{G}$ index. 
Most of the relevés with Papaver rhoeas represented winter crops (more than 47\%), in particular wheat $(30 \%)$. As to the root crops, there were three times more relevés with red poppy in potato than in sugar beet fields (Fig. 6), reflecting the crop structure in the RNP buffer zone in the first half of the 1990s and the fact that herbicides are applied much less frequently in potato crops compared to sugar beet crops. The studied species occurred in the highest degrees of cover-abundance chiefly on rendzinas, gaizes and other loamy soils, on idle land and recently fallowed fields, as well as in winter wheat crops.

The soil pH indicates that Papaver rhoeas tolerates substrates of various acidity. However, the smallest number of soil samples collected in the fields with this species was acidic (15\%) and basic (6.54\%). Almost $80 \%$ of the samples represented slightly acidic and neutral soils (Fig. 7).

The chemical analyses of 46 samples showed that Papaver rhoeas was considerably more frequent on the soils with calcium carbonate (approximately 67\% of samples), even in small quantities (under $2 \%$ ), than on the soils without this compound in the arable layer (Fig. 8). The soils on which Papaver rhoeas occurred in the RNP buffer zone were characterised by a wide range of potassium and phosphorus content, with the prevalence of moderate and high phosphorus content, and moderate, high and very high potassium content (Fig. 10). Low and very low concentration of magnesium was found in more than $60 \%$ of the samples (Fig. 11 ). The content of humus varied, but samples containing more than $2 \%$ of humus dominated (Fig. 12).

The average values of Ellenberg indicator T ranging from 1.8 to 3.3 suggest that Papaver rhoeas may equally occur in cold and warm sites, with the highest cover-abundance degrees found in the latter locations (Fig. 13). In most of the cultivated fields infested with poppy, $\mathrm{T}$ varied from 2 to 2.5 , i.e. from cold to moderately warm sites. This is also proved by the medians. The $\mathrm{T}$ values mainly depended on the type of soil, its granulometric composition and the location of fields in terrain relief. Rendzinas and brown soils developed from gaizes on southerly and south-westerly exposed slopes, and the lightest grey-brown podzolic soils were among the warmest ones. The range of the $\mathrm{W}$ indicator was equally wide, ranging from 2 to 3.8. However, regardless its cover-abundance, poppy occurred most frequently on optimally moist soils (W=2.7-3.3) (Fig. 14). Regarding the soil $\mathrm{pH}$, poppy was found within the whole range of $\mathrm{pH}$, from acid to basic soils, with at least the minimum cover-abundance "+." However, for higher degrees (1-4), the $\mathrm{pH}$ spectrum is far narrower, as revealed by the inter-quartile range and mid values corresponding to slightly acidic, neutral and basic habitats (Fig. 15). Obviously, the fact was taken into account that the study area was dominated by rendzinas and loamy brown soils, containing at least small amounts of $\mathrm{CaCO}_{3}$, for which the same value of $\mathrm{R}$ corresponds to a different $\mathrm{pH}$ from that in the case of light soils (E 11 e n b e r g , 1950). Also the average values of $\mathrm{N}$ representing nitrogen availability vary from almost 2.2 (poor) to 3.7 (rich). The values of the medians indicate that the species considered prefers soils moderately rich in nitrogen (Fig. 16). The average $G$ values for the cultivated fields with red poppy in the RNP buffer zone varied from 2.0 to 3.7 . In the least biologically active soils, the studied species was present in the lowest cover-abundance degree " + ." The medians for the cover-abundance values of 1-4 indicate that red poppy prefers sites with biologically active soils (Fig. 17).

The distribution of Papaver rhoeas in the study area reflects the variability of the soil cover. In the northern, eastern and central part of the RNP buffer zone (Zamość Valley, Roztocze), where the species had most of its locations, there are the largest areas of rendzinas and brown soils developed from gaizes and loess (Fig. 1). In the south-western part of the buffer zone (Biłgoraj Plain), with light and acidic soils dominating, Papaver rhoeas was seldom found.

According to the recent studies carried out on rendzinas of the Zamość Valley (unpublished data), rich in Papaver rhoeas, flowery fields disappear, and Papaver rhoeas, though still common, occurs sparsely, usually along the field edges, less intensively treated with herbicides. One can guess that in the coming years Papaver rhoeas will join the group of species contributing to the list of weeds threatened in that area and the entire RNP buffer zone.

\section{DISCUSSION}

The results of the study on the occurrence of Papaver rhoeas in agrocenoses of the RNP buffer zone largely converge with the data presented by other authors from the Lublin region and other regions of Poland.

Already thirty years ago, Fijałk ow ski (1978) demonstrated the dominance of Papaver rhoeas in Caucalido-Scandicetum and Lathyro-Melandrietum of cereal crops on rendzinas of the Zamość Valley and in other associations of Lubelszczyzna on rich and compact soils.

In the Kazimierz Landscape Park Papaver rhoeas reached the constancy class $\mathrm{V}$, but varying cover-abundance values in the associations Caucalido-Scandicetum and Consolido-Brometum ( $\mathrm{K} \mathrm{u}$ c h a r c z y k, 1999), floristically similar to Vicietum tetraspermae consolidetosum from the RNP buffer zone. Its dominance in the Caucalido-Scandicetum association was confirmed by S i c iń s k i (1993). In 
the Lathyro-Melandrietum association of the study area, Papaver rhoeas occurred more frequently and more abundantly than, for instance, in the Lower Vistula River valley (S z m e j a , 1987), CzarnorzekiStrzyżów Landscape Park (T ow pas z and B arabasz-Krasny, 2006). The abundance and frequency of Papaver rhoeas were also high in Delphinio consolidae-Brometum papaveretosum in the Przemyśl Foothills (W ó j c i k, 1998).

The presence of Papaver rhoeas in various variants of Vicietum tetraspermae (most abundant in $V$. $t$. consolidetosum) was confirmed by S k r z y c z y ń s k a (1994). The species concerned revealed the highest frequency and abundance in $V$. $t$. papaveretosum not only in the RNP buffer zone, but also in other regions of Poland (G łazek and W olak, 1991; T ow pas z and B a r a b a s z - Kr a s n y, 2006; W ó j c i k, 1977). Similarly like in the RNP buffer zone, frequently, but sparsely, this species was observed in Vicietum tetraspermae typicum (K u c h a r c z y k, 1999; A n i o łKwiatkowska and Nowak, 2006), and in montane variants of the association (H o c h ó ł, 2001; W ó j c i k, 1977).

The influence of relief and intensity of nitrogen fertilization on weed infestation of rape and winter wheat crops treated with herbicides was proved by Ję dru s z c z a k et al. (1994). On loess soils, Papaver rhoeas occurred more abundantly in winter wheat and in valleys than in rape and on southerly exposed slopes. The increase of the nitrogen dose above the level of $100 \mathrm{~kg} \mathrm{ha}^{-1}$ reduced the participation of Papaver rhoeas in weed infestation of both kinds of crops.

In Poland, according to the review made by W nuk (1987), Papaver rhoeas occurs on chalk and Jurassic rendzinas in all variants of the Lamio-Veronicetum politae associations. In the typical subassociation, it reached the constancy classes II-V and, as in the RNP buffer zone, high cover-abundance values. This subassociation is an indicator of sites rich in $\mathrm{CaCO}_{3}$ (S krzyczyńska, 1994; T ow pasz and B a r a b a s z - Krasny, 2006; Wnuk, 1987). On poorer soils with lower $\mathrm{pH}$ values, Lamio-Veronicetum politae with Fumaria officinalis develops in Poland. Depending on the region, Papaver rhoeas either does not occur at all or it is frequent and abundant ( $\mathrm{W} \mathrm{n} \mathrm{u} \mathrm{k}$, 1987), or, as in the RNP buffer zone, in the constancy class V, but with low cover. In Echinochloo-Setarietum, similarly to the RNP buffer zone, it was infrequent in the Przemyśl Foothills (T ow pas z and B a r a b a s z - Kr a s n y, 2006; W ó j c i k, 1998) and in the Siedlce Plateau (S k r z y c z y ń s k a, 1994), and more frequent in the Galinsogo-Setarietum typicum association in Opole Silesia (A n i o f - K w i a t k ow $\mathrm{s} \mathrm{k} \mathrm{a} \mathrm{and} \mathrm{N} \mathrm{ow} \mathrm{a} \mathrm{k,} \mathrm{2006).} \mathrm{The} \mathrm{species} \mathrm{was} \mathrm{not} \mathrm{found}$ in these associations in the Kazimierz Landscape Park (K u c h a r c z y k, 1999).

Among other associations accompanying cereal crops in Poland, which do not occur in the RNP buffer zone, Papaver rhoeas was found in the association Aphano-Matricarietum (A n i o $-\mathrm{K}$ w i a t k o w s k a and Nowak, 2006; R a ts zniak and Sobis Z, 2001), Papaveretum argemones (J a c k ow i a k et al. 1999; Ratuszniak and Sobisz, 2001; Skrzyczyńska, 1994) and in the montane association Holco-Galeopsietum (H o c h ó ł, 2001). In root crops, the studied species occurred in the constancy classes I-V almost in all varieties of OxalidoChenopodietum polyspermi, equally in the lowland and foothills, in river and stream valleys (W ó j c i k, 1998; 2001).

The cultivation method has an important influence on the occurrence of Papaver rhoeas ( $\mathrm{Z}$ a w i e ja et al. 2000). According to other authors and our own studies, it is more frequent and abundant in cereal crops, in particular winter crops, than in root crops ( $\mathrm{abza}, 1994$; Trąba and Wolański, 2003; Ziemińska-S m y k and Trąba, 2004). It grows very abundantly, as in the RNP buffer zone, on idle and recently fallowed land (K o r c z y ń s k i, 1998; R o la and R o la, 2003). In winter rape crops of Lubelszczyzna, it reached far higher constancy classes and cover indices than in spring rape (K a p e l u s z n y, 2003).

The influence of the farming system on weed infestation (including red poppy) of winter wheat crops on grey-brown podzolic soils developed from loamy sand and light loam was shown by F e le d y n S zewczyk and Duer (2004). In the third year of the study, the species in question persisted only in wheat grown in an organic farming system. It was not found in conventionally grown wheat crops or in monoculture. The high degree of Papaver rhoeas weed infestation of crops on rich soils in organic farms was found, among others, by R o la and R o l a (2003).

The wide ecological scale of Papaver rhoeas in the RNP buffer zone regarding type of soil, its granulometric composition and soil-agricultural complexes was confirmed by H o chół (2001), Ła b z a (1994), R ol a and R ol a (2003), W n u k (1996) and others. In the Kraków region ( $\mathrm{a} \mathrm{b} \mathrm{z} \mathrm{a} \mathrm{,} \mathrm{1994)} \mathrm{and} \mathrm{in} \mathrm{Beskid}$ Wyspowy (H o c h ó ł, 2001), it dominated on alluvial soils of mountain complexes, while it was less frequent on slopes. In both cases, it infested cereal crops in a very high or high degree. On rendzinas of the wheat defective complex in the Kraków region, $\mathrm{Pa}$ paver rhoeas infested crops at a moderate level, while on rendzinas of the good and very good wheat complex it occurred sporadically. It was not found in that region on the weak and very weak rye complex as well as on 
the weak cereal-fodder complexes ( $\mathrm{E}$ a b z a , 1994). The research by Rola and Rola (2003) indicates that the species concerned grows in masses on soils of wheat complexes and sporadically in rye complexes. W n u k (1996) mentions Papaver rhoeas among burdensome agricultural weeds in the Częstochowska Upland on soils of the good wheat, defective wheat, and very good rye complexes. W a r c h o li ń s k a (1998) determined that the highest concentration of Papaver rhoeas stands was in the river valleys of central Poland.

In the RNP buffer zone, Papaver rhoeas infested winter cereals in a very high degree on chalk rendzinas developed from loams and on leached loamy brown soils on gaizes, in a high degree spring cereal crops on rendzinas, and in a moderate degree root crops on those soils. The dominating complex was the defective wheat complex. The mentioned types of crops on other soil units were infested in a small or very small degree. Papaver rhoeas was not recorded on the lightest sandy soils and in the case of potato cultivation also on loess (Ziemińska-S m y k and Trąba, 2004).

J ę d r u s z c z a k (1998) found high constancy classes of Papaver rhoeas in cereal stubble fields of the Kielce region, central Poland, on rendzinas, alluvial soils, chernozem, Eutric Vertisols and loess brown soils. According to the author, the abundant Papaver rhoeas seed bank in the arable layer of these rich soils substantiates the commonness of the species.

As in the RNP buffer zone, Papaver rhoeas was widespread on heavy rendzinas of the Kazimierz Landscape Park. It occurred abundantly on loamy soils of the Przemyśl Foothills (W ó j c i k , 1998) and Siedlce Plateau (Skrzyczyńs ka, 1994). On the contrary, it was rare on loess soils of the Przemyśl Foothills (W ó j c i k , 1998) and the Rzeszów Foothills (T rą ba, W olańs ki , 2003), and it was absent on sandy soils of the Kolbuszowa Plateau ( $\mathrm{Tr}$ a b a and W o lańs ki , 2003).

K a p e lu s z n y (1988) proved that on rendzinas of the Lublin Upland the increased infestation of winter wheat with Papaver rhoeas caused a reduction in yield. He determined the critical weed density threshold before wheat harvest, substantially reducing its yield, at a level of 6-10 poppy individuals per $1 \mathrm{~m}^{2}$ and approximately $10 \%$ of other weeds.

Numerous weed species evidently react to soil $\mathrm{pH}(\mathrm{E} 11$ e $\mathrm{n}$ b e r g , 1950). Among them there are those that occur exclusively or predominantly on rendzinas, particularly in the southern and central regions of Poland, which are the warmest (Fijałk ow ski and Nycz, 1998; S i ciński, 1993; Trąba and Zi e m iń s k a - S m y k, 1998; W n u k, 1987). There are also less specialized species, moderately calciphilous, neutrophilous. The results presented in the present paper and in the literature data ( $\mathrm{G}$ $\mathrm{a}$ z e $\mathrm{k}$ and $\mathrm{W}$ o $\mathrm{l} \mathrm{a} \mathrm{k}$, 1991; W nuk, 1987; K orniak and Hołdyńs ki, 2001; S k r z y c z y ń s k a , 1994; J a c k o w i a k et al. 1999; Anioł-Kwiatkowska and Nowak, 2006) support the thesis that Papaver rhoeas belongs to such a group.

In the RNP buffer zone, Papaver rhoeas found optimal growth conditions on slightly acidic and neutral soils, although it was also spotted on acid and basic soils. Its wide ecological scale, regarding soil $\mathrm{pH}$, was revealed by several studies (e.g. F i j a ł k o w s k i, 1978; W n u k, 1987).

An important supplement to laboratory soil analyses is phytoindication, confirming the wide ecological amplitude of Papaver rhoeas in the RNP buffer zone, on the one hand, and optimal growth conditions, on the other hand. The importance of segetal plants as bioindicators in the assessment of arable sites has been stressed by numerous authors, including Borowiec (2003), H o chół (2001), Ł a b z a (1994), Trą b a (2001), W ó j c i k (1977), and A f te k - S t a r c z e w s k a (2007) in her review paper. Warmth and good soil structure can partially compensate the calcium deficit, a favourable circumstance for Papaver rhoeas and other calciphilous species, enabling them to grow even on acid soils (A f t e k - S t a r c z e w s k a, 2007).

L a t o w s ki (2002), on the basis of comparative analysis of floristic monographs, containing data from nine macroregions covering the entire Polish territory, showed that Papaver rhoeas was relatively common or rare only in five macroregions located in the central and southern part of the country. Ratyńska and Boratyński (2000) suggested that active conservation measures should be taken in order to protect plant communities with a high proportion of threatened species, including Papaver rhoeas. Such protection is possible, among others, in organic farms, agro-reserves, ethnographic parks, national and landscape parks.

In the 1990s Papaver rhoeas was frequent and abundant in the buffer zone of the Roztocze National Park (Ziemińska-S myk and Trąba, 2004) and for this reason it was not placed on the list of threatened weed species of that area ( $\mathrm{Tr}$ a b a and Zi e mińs k a, 1998).

\section{CONCLUSIONS}

1. Based on our own studies and the information from the literature, it was found that Papaver rhoeas occurred in associations and communities belonging to the Caucalidion and Aperion alliances accompanying cereal and rape crops, and to the PolygonoChenopodion and Panico-Setarion alliances in root crops. 
2. The wide ecological spectrum of Papaver rhoeas in the RNP buffer zone and other Polish regions is confirmed by its presence in lowland as well as in uplands and foothills, in river valleys and on slopes, on different soil units, lowland and mountain complexes, with a wide spectrum of soil $\mathrm{pH}$, trophic and thermal conditions as well as moisture content.

3. Papaver rhoeas occurs most frequently and abundantly in winter crops of the Lathyro-Melandrietum and Caucalido-Scandicetum associations of the Caucalidion alliance, and in Consolido-Brometum, Vicietum tetraspermae papaveretosum and $V$. t. consolidetosum of the Aperion alliance, while in root crops in the Lamio-Veronicetum politae association of the Polygono-Chenopodion alliance. It prefers chalk and Jurassic rendzinas containing calcium carbonate and other rich loamy and loess soils, from slightly acidic to basic (Eutric Vertisols, chernozems, brown soils, alluvial soils), moderately moist, warm, medium-rich in nitrogen, biologically active, belonging to wheat complexes. In piedmont areas, it dominates in river valleys on alluvial soils, less frequently on slopes.

4. Red poppy usually does not occur on lighter, acid sandy soils of the weak rye and very weak complex as well as the cereal-fodder complex.

5. Based on the results achieved in the RNP buffer zone, one can suppose that the species distribution and abundance of its population reflect the soil conditions.

\section{REFERENCES}

A f tek-St a rczewsk a A., 2005. Wykorzystanie metod fitoindykacyjnych $\mathrm{w}$ ocenie siedlisk rolniczych. / The use of phytoindicative methods for assessment of agricultural habitats. Zesz. Nauk. AP w Siedlcach Rol. 66/67: 107-128.

Anioł-Kwiatkowska J., Nowak S., 2006. Flora i roślinność segetalna parku krajobrazowego „Góra św. Anny” na Śląsku Opolskim. / Segetal flora and vegetation of the St. Ann Mountain Landscape Park in Opole Silesia. Pam. Puł., 143: 5-16.

B orowiec S., 2003. Roślinność segetalna jako bioindykatory. [In:] J. Ratuszniak (ed.), Rośliny segetalne. Bioindykacja-Chorologia-Zmienność: 7-11. Wyd. Pom. Akad. Pedag. Słupsk.

Dąbkowska T., Łabza T., Krańska A., 2007. Zmiany we florze chwastów segetalnych w latach 1993-2005 zagrożonych na rędzinie brunatnej Wyżyny Miechowskiej. / Changes in segetal weed flora threatened on brown rendzina of the Miechów Upland in the years 1993-2005. Fragm. Agron. XXIV, 3 (95): 55-61.

E1lenberg H., 1950. Unkrautgemeinschaften als Zeiger für Klima und Boden Landwirtschaftliche. Pflanzenzoziologie, 2, Stuttgart/Ludwigsburg, 141.
Feledyn-Szewczyk B, Duer I., 2004. Oddziaływanie systemu produkcji na zachwaszczenie łanu pszenicy ozimej. / The influence of crop production system on weed infestation in winter wheat. Pam. Pul., 138: 35-49.

Fijał kow sk i D., 1978. Synantropy roślinne Lubelszczyzny. / Synanthropic plants of the Lublin region. Państwowe Wyd. Nauk Warszawa-Łódź, 260.

Fijałkowski D., Nycz B., 1998. Zagrożone gatunki roślin segetalnych na Lubelszczyźnie. / Threatened species of segetal plants in the Lublin region. Acta Univ. Lodz. Folia bot. 13: 199-208.

G ła zek T., Wolak J., 1991. Zbiorowiska roślinne Świętokrzyskiego Parku Narodowego i jego strefy ochronnej. / Plant communities of the Świętokrzyski National Park and its buffer zone. Monogr. Bot. 72: 94-96.

Hilbig W., Mahn E. G., Schubert R., Wienden roth E. M., 1962. Die ökologisch - soziologischen Artengruppen der Ackerunkrautvegetation Mitteldeutschlands. Bot. Jb. 81: 416-449.

Ho chół T., 2001. Flora i zbiorowiska chwastów zbóż w Beskidzie Wyspowym w zależności od usytuowania siedlisk. / Segetal flora and communities in the Beskid Wyspowy Mts. depending on habitat location. Fragm. Agron., XVIII, 3 (71): 7-122.

Jackowiak B., Chmiel J., Latuczki K., 1994. Zbiorowiska segetalne zbóż ozimych Wielkopolski. / Segetal communities in winter cereal crops in the Wielkopolska region. Bad. Fizjogr. nad Polską Zach., VLIII, Ser. BBotanika: 105-124.

J ę d r u s z c zak M., 1993. Studia nad wybranymi fazami rozwojowymi chwastów w łanach roślin uprawnych. / Studies on selected developmental phases of weeds in crop fields. Rozpr. Hab. AR Lublin, 87.

Jędruszczak M., Orlik T., Dąbek-Gad M., 1994. Rzeźba i nawożenie azotem jako czynniki kształtujące zachwaszczenie łanu rzepaku ozimego i pszenicy ozimej na erodowanych glebach lessowych. / Relief and N fertilization as factors of weed infestation formation in winter rape and winter wheat canopy on eroded loess soil. Rocz. AR Pozn. 266, Melior. Inż. Środ. 14: 377-387.

Jędruszczak M., 1998. Status zagrożonych gatunków chwastów na ścierniskach zbożowych Kielecczyzny. / Status of threatened weed species on cereal stubblefields in the Kielce region. Acta Univ. Lodz. Folia bot. 13: 191-198.

K a pelu s z n y J., 1988. Krytyczne zagęszczenie maku polnego - (Papaver rhoeas L.) w pszenicy ozimej. / Critical density of field poppy - Papaver rhoeas L. in winter wheat. Zesz. Probl. Post. Nauk Rol. 349: 41-45.

Kapeluszny J., 2003. Rośliny o właściwościach leczniczych, nektarodajne i pyłkodajne w uprawach rzepaku na Lubelszczyźnie. / The medicinal, nectariferous and polleniferous weeds in oilseed rape (Brassica napus L. var. napus) in the Lublin region. Pam. Puł. 134: 113-120.

Korczyński M., 1998. Przemiany i stan flory segetalnej Bydgoszczy. / Changes and state of segetal flora in Bydgoszcz. Acta Univ. Lodz. Folia bot., 13: 65-72. 
Korniak T. Hołdyński C., 2001. Kalcyfilne gatunki chwastów polnych w północno-wschodniej Polsce. / Calciphilous species of field weeds in North-Eastern Poland. Acta Botanica Warmiae et Masuriae, 1: 131-139.

K u c h a r c z y k M., 1999. Zespoły i zbiorowiska roślinne Kozimierskiego Parku Krajobrazowego. IV. Zespoły i zbiorowiska synantropijne. / Plant associations and communities of Kazimierz Landscape Park. IV. Synanthropic associations and communities. Ann. UMCS, Sect. E, LIV: 184-255.

L at ow ski K., 2002. Problem pospolitych chwastów segetalnych w Polsce. / Problems of common segetal weeds in Poland. Prog. in Plant. Protec./Post. w Ochr. Rośl. 42 (1): 392-399.

Litýn ska-Zając M., 2005. Chwasty w uprawach roślinnych w pradziejach i wczesnym średniowieczu. / Segetal weeds in prehistoric and early mediewal farming. Wyd. Instytutu Archeologii i Etnologii PAN, Kraków, 444.

Łabz a T., 1994. Ekologiczne i rolnicze aspekty zachwaszczenia upraw zbożowych i okopowych w województwie krakowskim. / Ecological and agricultural aspects of tweed infestation of cereals and root crops in the province of Kraków. Zesz. Nauk. AR w Krakowie, Rozprawy, 194, 122.

Markow M., 1978. Agrofitocenologia. / Agrophytocenology. Państwowe Wyd. Roln. i Leśne, Warszawa, 267.

Matuszkiewicz W., 2005. Przewodnik do oznaczania zbiorowisk roślinnych Polski. / The guide for the identification of plant communities in Poland. Państw. Wyd. Nauk. Warszawa: 537.

P aw lak G., 1998. Ginące i zagrożone gatunki flory segetalnej w Konińskim Okręgu Przemysłowym. / Endangered and threatened species of the segetal flora in the Konin industrial district. Acta Univ. Lodz. Folia Bot. 13: 93-100.

Pawłowski F., Kapeluszny J., Kolasa A., Lecyk Z., 1970. Płodność chwastów w różnych siedliskach. / The prolificacy of weeds in various habitats. Ann. UMCS, Sect. E.

Ratuszniak I., Sobisz Z., 2001. Zbiorowiska segetalne Parku Krajobrazowego „Dolina Słupi”. Cz. II. / Segetal communities of the „Stupia River Valley” Landscape Park. Part II. Bad. Fizjogr. nad Polską Zach., Ser. BBotanika, 50: 63-79.

Ratyńska H., Boratyński A., 2000. Czynna ochrona roślin i zbiorowisk segetalnych i ruderalnych. / Active protection of segetal and ruderal plants and vegetation. Przegl. Przyr. XI (2-3): 43-56.

Rola H., Rola J., 2003. Chwasty o właściwościach leczniczych w zbiorowiskach segetalnych Dolnego Śląska / The weeds with medicinal properties in segetal communities of Lower Silesia. Pam. Pul. 134: 173-178.

S i c i ń s k i J., 1993. Warstwowość zbiorowisk chwastów zbóż ozimych. / Stratification of weed communities inhabiting wintercrops. Acta Agrobot. 46 (25): 65-75.

Skrzyczyńska J., 1994. Studia nad florą i zbiorowiskami segetalnymi Wysoczyzny Siedleckiej. / Studies on flora and segetal communities of the Siedlce Upland. Rozpr. Nauk. WSR-P w Siedlacach, 39, 145.

Szmeja K., 1987. Lathyro-Melandrietum Oberd. 1957 na czarnych ziemiach puławskich w dolinie Dolnej Wisły. / Lathyro-Melandrietum Oberd. 1957 on the black soil of Gniew in the Lower Vistula Valley. Zesz. Nauk. AR w Krakowie 216, Sesja Nauk. 19: 137-147.

Towpasz K., Barabasz-Krasny B., 2006. Zróżnicowanie roślinności segetalnej na obszarze CzarnorzeckoStrzyżowskiego Parku Krajobrazowego. / Differentiation of segetal vegetation in the Czarnorzeki-Strzyżów Landscape Park. Pam. Puł. 143: 183-192.

Trąba C., Wolański P., 2003. Udział roślin leczniczych w zbiorowiskach segetalnych na niektórych glebach południowo-wschodniej Polski. / Proportion of medicinal plants in segetal communities on selected soils of southeastern Poland. Pam. Puł. 134:239-246.

Trąba C., Ziemińska M., 1998. Stan gatunków chwastów segetalnych uważanych za zagrożone w otulinie Roztoczańskiego Parku Narodowego. / State of threatened segetal species in the buffer zone of the Roztocze National Park. Acta Univ. Lodz., Folia bot. 13: 265-272.

Trąb a C., 2001. Fitoindykacyjna ocena uwilgotnienia i warunków termicznych kompleksów pszennych i żytnich Kotliny Sandomierskiej. [In:] I. Ratuszniak, E. Ratuszniak, Z. Sobisz, M. Truchan (eds), Rośliny segetalne. Bioindykacja - Chorologia - Zmienność: 125-132. Wyd. Pomorska AP, Słupsk (in Polish).

Turski R., Uziak S., Zawadzki S., 1993. Środowisko przyrodnicze Lubelszczyzny. / The natural environment of the Lublin region. Lubelskie Tow. Nauk., 106.

Urbisz A., Urbisz A., Nowak T., 1998. Występowanie zagrożonych gatunków flory segetalnej na Wyżynie Śląskiej. / Occurrence of threatened species of the segetal flora in the Silesian Upland. Acta Univ. Lodz., Folia Bot. 13: 225-232.

Warcholińska U., 1994. List of threatened segetal plant species in Poland. Proc. of Intern. Conf., Sátoraljaújhely, 22-26 August, 1994: 206-219.

Warcholińska A. U., 1998. Stan i rozmieszczenie niektórych chwastów polnych w środkowej Polsce. / State and distribution of some segetal weeds in central Poland. Acta Univ. Lodz., Folia Bot. 12: 115-130.

Wnuk Z., 1987. Zespół Lamio-Veronicetum politae Kornaś 1950 w Polsce. / Lamio-Veronicetum politae Kornaś 1950 in Poland. Zesz. Nauk. AR w Krakowie 216, Sesja Nauk. 19: 95-133.

Wnuk Z., 1996. Gatunki chwastów uciążliwe dla rolnictwa na wyżynie Częstochowskiej. / Weed species arduous for agriculture in the Częstochowa Upland. Zesz. Nauk. ART Bydgoszcz 196, Rol. 38: 43-51.

Wójcik Z., 2001. Oxalido-Chenopodietum polyspermi SISINGH 1942 - zespół chwastów upraw okopowych dolin rzecznych i pogórzy w Polsce. / Typologia zbiorowisk i kartografia roślinności w Polsce. Oxalido-Chenopodietum polyspermi SISINGH 1942 - an association 
of weeds of root crops in river valleys and foothills of Poland. Pr. Geogr., 178: 87-117.

Wój ci k Z., 1977. Charakterystyka siedlisk polnych na Pogórzu Beskidu Niskiego metodami biologicznymi. / Determination of field habitats by biological methods on the Low Beskid Foothills and their immediate neighbourhood. Prace Geogr., PAN, 121, 111.

Wójcik Z., 1998. Zbiorowiska segetalne Pogórza Przemyskiego i jego najbliższego otoczenia. / Segetal communities of the Przemyśl Foothills and its immediate surroundings. Fragm. Flor. Geobot., Ser. Polonica, 5: $117-164$

Zalecenia nawozowe, 1985. Cz. I. Liczby graniczne do wyceny zawartości w glebach makro- i mikroelementów. / Fertilising recommendations. I. Threshold numbers for the macro- and microelement evaluation in soils. Ser. P (29), IUNG Puławy, 34.

Zawieja J., Wojciechowski W., Wacławowicz R., 2000. Wpływ zróżnicowanej uprawy roli na liczebność i pionowe rozmieszczenie diaspor chwastów w glebie pod monokulturą pszenicy ozimej. / Influence of varying soil tillage on the number and vertical distribution of weed seeds in soil of winter wheat monoculture. Ann. UMCS, Sect. E., LV, Suppl. 29: 239-244.

Ziemińska-Smyk M., Trąba C., 2004. Zachwaszczenie roślin uprawnych na różnych glebach otuliny Roztoczańskiego Parku Narodowego. Cz. I i II. / Weed infestation of field crops in different soils in the protective zone of the Roztocze National Park. Part I and II. Acta Agrobot. 57 (1-2): 207-229.

\section{Występowanie Papaver rhoeas $\mathrm{L}$. w agrocenozach otuliny Roztoczańskiego Parku Narodowego na tle innych regionów Polski}

\section{Streszczenie}

W pracy podjęto próbę ustalenia amplitudy ekologicznej oraz warunków optymalnych w jakich rośnie Papaver rhoeas w agrocenozach otuliny Roztoczańskiego Parku Narodowego na tle innych regionów w Polsce, w zależności od niektórych czynników siedliskowych i antropogenicznych. Na podstawie ba- dań własnych i danych z literatury stwierdzono, że $P a$ paver rhoeas występuje w zespołach i zbiorowiskach zarówno ze związku Caucalidion, jak i Aperion towarzyszących uprawom zbóż i rzepaku oraz ze związku Polygono-Chenopodion i Panico-Setarion w uprawach okopowych. O szerokiej skali ekologicznej $\mathrm{Pa}$ paver rhoeas świadczy jego obecność na niżu, w pasie wyżyn i podgórzy, w dolinach rzecznych i na stokach, na różnych glebach i kompleksach niżowych oraz górskich, o szerokim zakresie odczynu gleb, warunków troficznych, termicznych i uwilgotnienia. Najczęściej i w największych stopniach ilościowości gatunek ten występuje w oziminach w zespołach Lathyro-Melandrietum i Caucalido-Scandicetum ze związku Caucalidion oraz Consolido-Brometum, Vicietum tetraspermae papaveretosum i $V$. t. consolidetosum ze związku Aperion, a w okopowych w zespole Lamio-Veronicetum politae ze związku Polygono-Chenopodion. Preferuje rędziny kredowe i jurajskie zawierające $\mathrm{CaCO}_{3}$ i inne żyzne gleby gliniaste lub lessowe o odczynie od lekko kwaśnego po zasadowy (czarne ziemie, czarnoziemy, brunatne, mady) umiarkowanie wilgotne, ciepłe, średnio zasobne w azot i o dobrej aktywności biologicznej zaliczane do kompleksów pszennych. $\mathrm{W}$ terenach podgórskich dominuje na madach w dolinach rzek, a rzadziej spotykany jest na stokach. Papaver rhoeas przeważnie nie występuje na najlżejszych glebach piaskowych kompleksów żytniego słabego i bardzo słabego oraz zbożowo-pastewnego słabego. Rozmieszczenie tego gatunku jest odzwierciedleniem warunków glebowych na danym terenie. 